\title{
Sürekli Kalite İyileştirme için Faktöriyel Tasarım Tabanlı Süreç Optimizasyonu
}

\author{
Akın Özdemir ${ }^{*}$, Metin Uçurum², Hüseyin Serencam ${ }^{3}$ \\ Geliş / Received: 28/11/2019 \\ Revize / Revised: 11/08/2020 \\ Kabul / Accepted: 12/08/2020
}

ÖZ

Deneyin tasarımı, yeni bir süreç geliştirmek veya mevcut bir süreci geliştirmek için kilit bir rol oynar. Literatürde sürekli kalite iyileştirme için faktöriyel deneysel tasarımları kullanılmıştır. Bu makalede, tasarım faktörlerinin optimizasyonu için bir deney verisi analizi yapmak amacıyla faktöriyel deney tasarımına sahip yeni bir yöntem sunulmaktadır. Önerilen yöntem beş ana adıma sahiptir. İlk adım deney öncesi planlama ile ilgilidir. İkinci adım faktöriyel tasarıma sahip deneysel aşamadır. Üçüncü adım bir deneye ait verileri analiz eder. Daha sonra, tasarım faktörlerinin en uygun değerlerini elde etmek için faktöriyel tasarıma dayalı optimizasyon modeli ilk defa geliştirilmiştir. Son adım deneyden elde edilen sonuçları doğrulamak için sonuçlar ve tavsiyeler adımdır. Son olarak, güncel literatürdeki sayısal bir örnek için farklı hedef değerler kullanılarak karşılaştırma çalışmaları yapılmıştır. Ayrıca, önerilen faktöriyel tasarıma dayalı süreç optimizasyon modelinin belirtilen hedef değere göre daha fazla varyansı azaltabileceği sonucuna varılmışıır.

Anahtar Kelimeler- Kalite Mühendisliği, Faktöriyel Deney Tasarımı, Belirlenmiş Hedef Değer, Süreç Optimizasyonu

\footnotetext{
1*Sorumlu yazar iletișim: akin.ozdemir@omu.edu.tr (https://orcid.org/0000-0002-1716-6694)

Endüstri Mühendisliği Bölümü, Ondokuz Mayıs Üniversitesi, Samsun, 55139, Türkiye

2İletișim: mucurum@bayburt.edu.tr (https://orcid.org/0000-0002-0725-9344)

Endüstri Mühendisliği Bölümü, Bayburt Üniversitesi, Bayburt, 69000, Türkiye

3İletişim: hserencam@trabzon.edu.tr (https://orcid.org/0000-0001-8893-8914)

Gastronomi ve Mutfak Sanatları Bölümü, Trabzon Üniversitesi, Trabzon, 61300, Türkiye
} 


\title{
Factorial Design-Based Process Optimization for Continuous Quality Improvement
}

\begin{abstract}
The design of the experiment plays a key role to develop a new process or improve an existing process. In the literature, factorial experimental designs are used for continuous quality improvement. This paper presents a novel methodology with a factorial experimental design in order to conduct an experiment data analysis for the optimization of design factors. The proposed methodology has five main steps. The first step is related to preexperimental planning. The second step is the experimental phase with a factorial design. The third step analyzes data for an experiment. Next, a factorial design-based optimization model is firstly developed to get the optimal settings of design factors. The last step is the conclusions and recommendations step in order to validate the conclusions from the experiment. Finally, comparison studies are performed using the different target values for a numerical example from the current literature. In addition, it was concluded that the proposed factorial designbased process optimization model could reduce more variance based on the specified target value.
\end{abstract}

Keywords- Quality Engineering, Factorial Experimental Design, Specified Target Value, Process Optimization 


\section{INTRODUCTORY REMARKS}

Factorial designs are widely used for many processes [1]. A factorial design is one of the experimental design techniques, and it has $k$ design factors and each design factor has two coded levels, which are low coded and high coded levels. This type of factorial experimental design is known as a $2^{k}$ factorial design. A comprehensive review of factorial designs was provided by Montgomery [1]. Besides, factorial design-based process optimization is to obtain optimum operating conditions of design factors by using a factorial design.

In the literature, Vining and Myers [2] proposed the dual response model, which is to minimize the estimated process variance when the estimated process mean value is at the target value. They used response surface design for the design phase and the Lagrange multiplier method for the optimization method. Then Del Castillo and Montgomery [3] enhanced the dual response approach with a generalized reduced gradient method while considering response surface designs. Besides, Lin and Tu [4] proposed a mean-squared error (MSE) model while considering the process bias and variance at the same time. They used a standard subroutine in a nonlinear programming technique. Later, Copeland and Nelson [5] improved the MSE model using the desired distance for the process bias, and they demonstrated the Nelder-Mead simplex method.

While considering multiple criteria optimization problems, Ames et al. [6] offered a quadratic loss function-based process optimization model for response surface models to find the optimal setting for design factors. Along the same lines, Borror [7] introduced an optimization model with a desirability function for the designed experiment. For flexibility, Kim and Lin [8] introduced a fuzzy optimization model to optimize a dual response system when incorporating membership functions. Besides, Kim and Cho [9] developed an integrated design optimization model to incorporate the tolerances on design parameters with tolerance-related costs. Moreover, Kim and Cho [10] introduced a priority-based optimization model using a nonlinear goal programming technique for the response surface approach. While considering unusual weights for the process variance and bias, Tang and $\mathrm{Xu}$ [11] proposed another form of the dual response model with the unified formulation. Besides, they used a goal programming approach to optimize the dual response system.

Ding et al. [12] and Shin et al. [13] offered the weighted sum method with the MSE approach in the concept of multi-objective optimization while considering second-order polynomial approximation models. Koksoy [14] and Park et al. [15] studied the weighted MSE models by using fourth-order polynomial functions for the multi-objective optimization problems. In addition, Shaibu and Cho [16] developed an optimization model while considering the desired target value and the process variance using higher-order approximation models. They also developed dual response surface optimization models for each of the three classes of quality characteristics. Next, Costa [17] introduced a model by using each quality interest from the specified target values to minimize the objective function. Costa [17] also reviewed the optimization methods for dual response models using response surface designs. Then Park [18] applied to the bootstrap method to obtain joint confidence regions into the optimum operating conditions. Park [18] also introduced Bonferroni and multivariate normal approximation. Furthermore, Shin et al. [19] proposed an optimization model to obtain the optimal pharmaceutical formulation with the time series target profiles for a pharmaceutical process.

Recent studies in this area were conducted by Chan and Ozdemir [20], Ozdemir and Cho [21, 22], Lu et al. [23], Chartterjee et al. [24], Ouyang et al. [25], Ozdemir [26], and Ozdemir and Cho [27] illustrated a wide spectrum of optimization models, including response surface optimization models, interval programming models, dual response approaches for process optimization, and design optimization models for non-standard experimental design regions.

As shown in the current literature, there is no research attempt to develop a factorial design-based process optimization model to obtain optimum levels of design factors. Therefore, there are three main research contributions in this paper. First, the estimated response functions of process mean and variance are obtained by using the least-square method for a factorial design. Second, a factorial design-based process optimization model is firstly proposed to minimize the estimated process variance response function as possible while satisfying the three constraints. Finally, a numerical example from the current literature is given to optimize the design factors using the proposed factorial design-based process optimization model. Besides, comparison studies are performed 
using different target values. It is also observed that the selection of the target value could change the optimum levels of design factors while minimizing the estimated process variance.

The rest of this paper is organized as follows: First, the proposed methodology is presented in Section II with five steps. Then a numerical example is conducted in Section III. Comparison studies are also performed. Next, the discussion section is presented in Section IV. Finally, conclusions and further studies are drawn in Section V.

\section{PROPOSED METHODOLOGY}

The proposed methodology includes five steps, namely the pre-experimental planning step, the experimental step, the data analysis step, the optimization step, and the conclusions and recommendations step. Each of the steps is decribed in what follows.

\section{A. The Pre-Experimental Planning Step}

The first step of the proposed methodology is pre-experimental planning, and this step is related to how to increase the process of knowledge. Indeed, the process of knowledge is the key design factors that require further detailed analyses. The experimenter or researcher should choose design factors at two levels based on the experiences or prior knowledge about the product or process. Besides, design factors influence the product or process performance measure. This performance measure is a response variable. It is also noted that the response variable should be selected depending on key design factors for the process in this step.

\section{B. The Experimental Step}

A factorial design is chosen to experiment with process optimization in the experimental step. Besides, a number of experimental runs and the selection of a model order are important to the selection of experimental design. For the factorial design, the number of experimental runs is fewer and the first-order model with interaction terms is used. Therefore, the factorial design is a good choice for the experimenter or researcher. Notice that the factorial design is denoted geometrically as a cube or a square.

\section{The Data Analysis Step}

The least-square method is used to analyze data from a factorial design in this paper. For this particular purpose, the estimated process mean function is found in the following way:

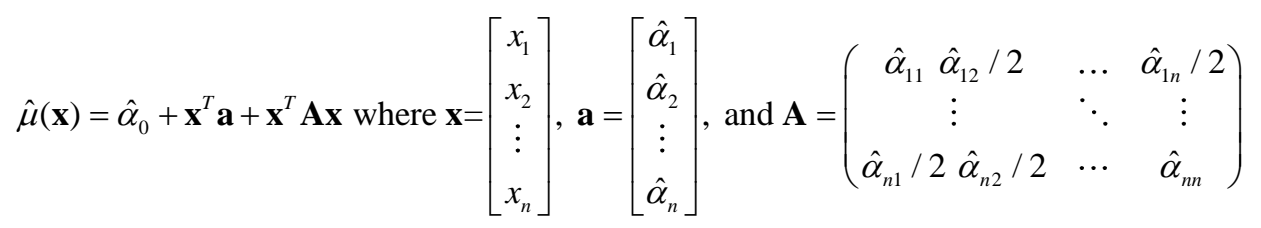

where $\hat{\alpha}_{11}=\hat{\alpha}_{22}=\ldots=\hat{\alpha}_{n n}=0$ due to the first-order and interaction terms, and $\alpha_{i}$ is the regression coefficient in the least-square method. $\mathbf{x}$ denotes the vector of the design factors of the experiment. In Equation (1), a and $\mathbf{A}$ represent the estimated regression coefficients.

The estimated process variance function is expressed as follows:

$$
\hat{\sigma}^{2}(\mathbf{x})=\hat{\beta}_{0}+\mathbf{x}^{T} \mathbf{b}+\mathbf{x}^{T} \mathbf{B} \mathbf{x} \text { where } \mathbf{x}=\left[\begin{array}{c}
x_{1} \\
x_{2} \\
\vdots \\
x_{n}
\end{array}\right], \mathbf{b}=\left[\begin{array}{c}
\hat{\beta}_{1} \\
\hat{\beta}_{2} \\
\vdots \\
\hat{\beta}_{n}
\end{array}\right] \text { and } \mathbf{B}=\left(\begin{array}{ccc}
\hat{\beta}_{11} \hat{\beta}_{12} / 2 & \ldots & \hat{\beta}_{1 n} / 2 \\
\vdots & \ddots & \vdots \\
\hat{\beta}_{n 1} / 2 \hat{\beta}_{n 2} / 2 & \ldots & \hat{\beta}_{n n}
\end{array}\right)
$$




\begin{tabular}{|c|c|c|}
\hline & $\begin{array}{l}\text { BŞEÜ Fen Bilimleri Dergisi } \\
7(2), 660-669,2020\end{array}$ & $\begin{array}{r}\text { BSEU Journal of Science } \\
\text { DOI: } 10.35193 / \text { bseufbd.651919 }\end{array}$ \\
\hline & & 58-7575 (http://dergipark.gov.tr/bseufbd) \\
\hline
\end{tabular}

where $\hat{\beta}_{11}=\hat{\beta}_{22}=\ldots=\hat{\beta}_{n n}=0$ due to the first-order and interaction terms, and $\hat{\beta}_{i}$ is the regression coefficient. In Equation (2), $\mathbf{b}$ and $\mathbf{B}$ represent the estimated regression coefficients.

\section{The Optimization Step}

The variance reduction is an important issue in quality engineering problems. Therefore, the objective function minimizes the estimated process variance function as follows:

$$
\text { Minimize } \hat{\sigma}^{2}(\mathbf{x})
$$

The proposed process optimization model has three constraints.

1. The process target related constraint: The estimated process mean is desired at the specified target value. This constraint is important to meet the customer's satisfaction. This constraint is denoted as follows:

$$
\hat{\mu}(\mathbf{x})=\mu_{\tau}
$$

where $\mu_{\tau}$ represents the specified target value by the customer. constraint is

2. Prevention of non-meaningful results: The estimated variance should not be a negative value. Thus, the

$$
\hat{\sigma}^{2}(\mathbf{x}) \geq 0
$$

3. Bounds for each design factor: A factorial experimental design consists of -1 and +1 coded levels for each design factor. Thus, an optimal solution to design factors could be found between -1 and +1 coded levels. Notice that a design region is either a square or $n$-cube. The bounds are

$-1 \leq x_{i} \leq+1$ and $i=1,2, \ldots, n$

Table 1 shows the factorial design-based proposed process optimization model.

Table 1. The proposed factorial design-based process optimization model

\begin{tabular}{ll}
\hline Minimize & $\hat{\sigma}^{2}(\mathbf{x}) \Rightarrow \hat{\beta}_{0}+\mathbf{x}^{T} \mathbf{b}+\mathbf{x}^{T} \mathbf{B} \mathbf{x}$ \\
\hline Subject to & \\
\hline I & $\hat{\mu}(\mathbf{x})=\mu_{\tau} \Rightarrow \hat{\alpha}_{0}+\mathbf{x}^{T} \mathbf{a}+\mathbf{x}^{T} \mathbf{A x}=\mu_{\tau}$ \\
II & $\hat{\sigma}^{2}(\mathbf{x}) \geq 0 \Rightarrow \hat{\beta}_{0}+\mathbf{x}^{T} \mathbf{b}+\mathbf{x}^{T} \mathbf{B} \mathbf{x} \geq 0$ \\
III & $-1 \leq x_{i} \leq+1$ and $i=1,2, \ldots, n$ \\
\hline
\end{tabular}

\section{E. The Conclusions and Recommendations Step}

Once steps one to four have been completed, the experimenter or researcher coulda conclude from the results of the factorial experimental design and give some recommendations about the process. The verification study is recommended for different target values in order to validate the results of the factorial design.

\section{NUMERICAL EXAMPLE}

A numerical example was used in this paper from Myers et al. [28]. Engineers at a semiconductor manufacturer conducted a $2^{4}$ factorial design in a vertical oxidation furnace [28]. The aim of the experiment was to analyze the effects of the four design factors in oxide thickness [28]. The four design factors are specified as temperature $\left(x_{1}\right)$, time $\left(x_{2}\right)$, pressure $\left(x_{3}\right)$, and gas flow $\left(x_{4}\right)$. The experiment measured the oxide thickness on all 
four wafers. Table 2 shows the data for the experiment. The design region is an $n$-cube because of the $2^{4}$ factorial experimental design. In Table 2 , the four columns $\left(y_{1}, y_{2}, y_{3}\right.$, and $\left.y_{4}\right)$ are the oxide thickness measurements on each wafer, and the last two columns $\left(\bar{y}\right.$ and $s^{2}$ ) are the sample mean and sample variance of thickness measurements on the four wafers in each experimental run. Besides, the Maple [29] software was used for the data analysis and optimization steps.

Table 2. The factorial experimental design for the oxide thickness experiment (please see Myers et al. [28])

\begin{tabular}{|c|c|c|c|c|c|c|c|c|c|c|c|}
\hline $\begin{array}{c}\text { Standard } \\
\text { Order }\end{array}$ & $\begin{array}{c}\text { Randomization } \\
\text { Order }\end{array}$ & $\begin{array}{c}x_{1} \\
\text { (Temperature) }\end{array}$ & $\begin{array}{c}x_{2} \\
\text { (Time) } \\
\end{array}$ & $\begin{array}{c}x_{3} \\
\text { (Pressure) }\end{array}$ & $\begin{array}{c}x_{4} \\
\text { (Gas Flow) } \\
\end{array}$ & $y_{1}$ & $y_{2}$ & $y_{3}$ & $y_{4}$ & $\bar{y}$ & $s^{2}$ \\
\hline 1 & 10 & -1 & -1 & -1 & -1 & 378 & 376 & 379 & 379 & 378 & 2.00 \\
\hline 2 & 7 & +1 & -1 & -1 & -1 & 415 & 416 & 416 & 417 & 416 & 0.67 \\
\hline 4 & 9 & +1 & +1 & -1 & -1 & 450 & 446 & 449 & 447 & 448 & 3.33 \\
\hline 5 & 6 & -1 & -1 & +1 & -1 & 375 & 371 & 373 & 369 & 372 & 6.67 \\
\hline 6 & 2 & +1 & -1 & +1 & -1 & 391 & 390 & 388 & 391 & 390 & 2.00 \\
\hline 8 & 4 & +1 & +1 & +1 & -1 & 426 & 433 & 430 & 431 & 430 & 8.67 \\
\hline 9 & 12 & -1 & -1 & -1 & +1 & 381 & 381 & 375 & 383 & 380 & 12.00 \\
\hline 10 & 16 & +1 & -1 & -1 & +1 & 416 & 420 & 412 & 412 & 415 & 14.67 \\
\hline 11 & 8 & -1 & +1 & -1 & +1 & 375 & 372 & 371 & 370 & 371 & 0.67 \\
\hline 12 & 1 & +1 & +1 & -1 & +1 & 445 & 448 & 443 & 448 & 446 & 6.00 \\
\hline 13 & 14 & -1 & -1 & +1 & +1 & 377 & 377 & 379 & 379 & 378 & 1.33 \\
\hline
\end{tabular}

The estimated mean response function was found using Equation (1) as follows:

$$
\begin{aligned}
\hat{\mu}(\mathbf{x})= & 399.19+21.56 x_{1}+9.06 x_{2}-5.19 x_{3}-0.81 x_{4}+8.44 x_{1} x_{2}-5.31 x_{1} x_{3}+0.56 x_{1} x_{4} \\
& +1.94 x_{2} x_{3}-1.94 x_{2} x_{4}+0.56 x_{3} x_{4}
\end{aligned}
$$

The estimated variance response function was found using Equation (2) as follows:

$$
\begin{aligned}
\hat{\sigma}(\mathbf{x})= & 6.13+2.71 x_{1}-3.04 x_{2}+0.79 x_{3}+2.71 x_{4}-0.96 x_{1} x_{2}+1.87 x_{1} x_{3}+2.46 x_{1} x_{4} \\
& -1.04 x_{2} x_{3}-3.62 x_{2} x_{4}-0.29 x_{3} x_{4}
\end{aligned}
$$

The specified target value is 400 for the oxide thickness experiment. Table 3 shows the proposed factorial design-based process optimization model with Equations (7-8). The Maple [29] sequential quadratic programming solver was used to obtain the results of design factors in Tables 4-6. The sequential quadratic programming was used because of the interaction terms in Equations (7-8).

Table 3. The proposed factorial design-based process optimization model for the oxide thickness experiment

\begin{tabular}{ll}
\hline Minimize & $6.13+2.71 x_{1}-3.04 x_{2}+0.79 x_{3}+2.71 x_{4}-0.96 x_{1} x_{2}+1.87 x_{1} x_{3}+2.46 x_{1} x_{4}$ \\
& $-1.04 x_{2} x_{3}-3.62 x_{2} x_{4}-0.29 x_{3} x_{4}$ \\
\hline Subject to & \\
\hline Constraint I & $399.19+21.56 x_{1}+9.06 x_{2}-5.19 x_{3}-0.81 x_{4}+8.44 x_{1} x_{2}-5.31 x_{1} x_{3}+0.56 x_{1} x_{4}$ \\
& $+1.94 x_{2} x_{3}-1.94 x_{2} x_{4}+0.56 x_{3} x_{4}=400$ \\
Constraint II & $6.13+2.71 x_{1}-3.04 x_{2}+0.79 x_{3}+2.71 x_{4}-0.96 x_{1} x_{2}+1.87 x_{1} x_{3}+2.46 x_{1} x_{4}$ \\
& $-1.04 x_{2} x_{3}-3.62 x_{2} x_{4}-0.29 x_{3} x_{4} \geq 0$ \\
Constraint III & $-1 \leq x_{i} \leq+1$ and $i=1,2,3,4$ \\
\hline
\end{tabular}


The results of design factors are shown in Table 4 for the factorial experimental design where the specified target value is 400 .

Table 4. Results of design factors where $\mu_{\tau}=400$

\begin{tabular}{lc}
\hline Design factor & Optimal coded level \\
\hline$x_{1}$ (Temperature) & -0.111 \\
$x_{2}$ (Time) & 1.000 \\
$x_{3}$ (Pressure) & 1.000 \\
$x_{4}$ (Gas Flow) & 1.000 \\
\hline
\end{tabular}

The estimated variance response function is obtained at 0.963 for the oxide thickness experiment. Tables 5 and 6 show the results of design factors while specifying different target values. For example, the process variance is $1.082 \mathrm{E}-15$ (almost zero) where the specified target value is 375 . On the other hand, the process variance is 1.208 where the specified target value is 445 . Thus, the choice of the specified target value is important to reduce the process variance and meet the customer's expectation.

Table 5. Results of design factors where $\mu_{\tau}<400$

\begin{tabular}{|c|c|c|c|c|c|}
\hline Design factor & $\begin{array}{c}\text { Optimal coded } \\
\text { level } \\
\text { for } \mu_{\tau}=375\end{array}$ & $\begin{array}{c}\text { Optimal coded } \\
\text { level } \\
\text { for } \mu_{\tau}=380\end{array}$ & $\begin{array}{c}\text { Optimal coded } \\
\text { level } \\
\text { for } \mu_{\tau}=385\end{array}$ & $\begin{array}{c}\text { Optimal coded } \\
\text { level } \\
\text { for } \mu_{\tau}=390\end{array}$ & $\begin{array}{c}\text { Optimal coded } \\
\text { level } \\
\text { for } \mu_{\tau}=395\end{array}$ \\
\hline$x_{1}$ (Temperature) & -0.945 & -0.864 & -0.662 & -0.477 & -0.306 \\
\hline$x_{2}$ (Time) & 0.975 & 0.508 & 0.702 & 0.840 & 0.977 \\
\hline$x_{3}$ (Pressure) & -0.725 & 0.860 & 0.806 & 0.918 & 0.997 \\
\hline$x_{4}($ Gas Flow $)$ & 1.000 & 1.000 & 0.999 & 0.999 & 0.975 \\
\hline $\begin{array}{l}\text { Objective } \\
\text { function value }\end{array}$ & $1.082 \mathrm{E}-15$ & $4.317 \mathrm{E}-11$ & $1.291 \mathrm{E}-13$ & $9.992 \mathrm{E}-16$ & $1.544 \mathrm{E}-12$ \\
\hline
\end{tabular}

Table 6. Results of design factors where $\mu_{\tau}>400$

\begin{tabular}{|c|c|c|c|c|c|}
\hline Design factor & $\begin{array}{c}\text { Optimal coded } \\
\text { level } \\
\text { for } \mu_{\tau}=405\end{array}$ & $\begin{array}{c}\text { Optimal coded } \\
\text { level } \\
\text { for } \mu_{\tau}=415\end{array}$ & $\begin{array}{c}\text { Optimal coded } \\
\text { level } \\
\text { for } \mu_{\tau}=425\end{array}$ & $\begin{array}{c}\text { Optimal coded } \\
\text { level } \\
\text { for } \mu_{\tau}=435\end{array}$ & $\begin{array}{c}\begin{array}{c}\text { Optimal coded } \\
\text { level }\end{array} \\
\text { for } \mu_{\tau}=445\end{array}$ \\
\hline$x_{l}$ (Temperature) & 0.023 & 0.178 & 1.000 & 1.000 & 1.000 \\
\hline$x_{2}$ (Time) & 1.000 & 1.000 & -0.403 & 0.168 & 0.739 \\
\hline$x_{3}$ (Pressure) & 0.426 & -1.000 & -1.000 & -1.000 & -1.000 \\
\hline$x_{4}$ (Gas Flow) & 1.000 & 0.871 & -1.000 & -1.000 & -1.000 \\
\hline $\begin{array}{l}\text { Objective function } \\
\text { value }\end{array}$ & 2.064 & 3.161 & 0.454 & 0.831 & 1.208 \\
\hline
\end{tabular}

Notice that no feasible solution could be found for the proposed factorial design-based process optimization model where the specified target value is, for example, 500 or 370 . This situation is a limitation of the proposed process optimization model. The achievement of the proposed process optimization model is based on the specified target value.

\section{DISCUSSIONS}

$\mathrm{R}^{2}$ (coefficient of determination) is $99.68 \%$ for the estimated mean response function. Besides, the estimated mean response function is well-estimated based on the $\mathrm{R}^{2}$ value. Each level of the temperature factor affects \pm 21.56 for the oxide thickness. This factor is important to satisfy the process target related constraint. The optimum levels of the temperature factor varied based on the specified target value. Then each level of the time factor affects \pm 9.06 for the oxide thickness. This design factor is important as well. In general, the optimum levels 
of the time factor were obtained at high levels. Next, pressure is an important factor to satisfy the process target related constraint. Each level of the pressure factor affects $\mp 5.19$ for the oxide thickness. The optimum levels of the pressure design factors were usually obtained at high levels when $\mu_{\tau}<400$. On the other hand, the optimum levels of the pressure design factor were usually obtained at low levels when $\mu_{\tau}>400$. Besides, the gas flow design factor is not more important than other design factors. It is also noted that the interaction term of the temperature and time design factors is important. Each level of this interaction term also affects \pm 8.44 for the oxide thickness. The optimum levels of the gas flow design factors were always obtained at high levels when $\mu_{\tau}<400$. On the other hand, the optimum levels of the gas flow design factor were often obtained at low levels when $\mu_{\tau}>400$. Besides, the interaction term of the temperature and pressure design factors is important. Each level of this interaction term also affects $\mp 5.31$ for the experiment. Next, the interaction term of the time and pressure design factors, and the interaction term of the time and gas flow design factors are important, and each level of these interaction terms affects \pm 1.94 for the experiment. Other interaction terms are not significant for the oxide thickness.

$\mathrm{R}^{2}$ is $71.36 \%$ for the estimated variance response function, and this value shows a good performance to estimate the process variance. Based on the main effects of the estimated variance response, the temperature, time, and gas flow design factors are significant to reduce the estimated process variance in the objective function. Besides, the interaction term of the temperature and pressure design factors, the interaction term of the temperature, and gas flow design factors, and the interaction term of the time and gas flow are significant to reduce the estimated process variance of the oxide thickness. It is also noticed that the process target related constraint affects the objective function of the proposed optimization model. The smallest estimated process variance value was obtained when $\mu_{\tau}=390$.

\section{CONCLUDING REMARKS AND FURTHER STUDIES}

Factorial designs are highly effective to analyze design factors for many process. For this particular purpose, a five-phased methodology is proposed in this paper for continuous quality improvement. For the experimental step, a two-level factorial experimental design is selected while considering the first-order and interaction terms. The process mean and variance functions are obtained with the experimental data from the twolevel factorial experimental design. Then a factorial design-based process optimization model is developed to obtain the optimal settings of design factors. In this paper, a numerical example is used from the current literature (please see Myers et al. [28]). The process variance was obtained as 1.082E-15 (almost zero) where the specified target value was 375 . On the contrary, the process variance was found as 1.208 where the specified target value was 445. Therefore, the results of this example show that the proposed methodology is useful to reduce the process variance for the experiment. Note that the specified target value is an important parameter to find a feasible solution setting for the proposed process optimization model.

There are three main limitations of this study. First of all, this paper just focused on the main and interaction effects of the regression model because two coded levels-based factorial designs analyze the main and interaction effects. For example, quadratic effects are not analyzed by using two coded levels-based factorial designs. Second, the proposed methodology works well for a response variable. For more than one variable, the proposed methodology is not effective to obtain optimum conditions. Finally, the results of design factors are based on the specified target value.

For further studies, an extension of this paper could be to build a second-order model to analyze the data. For this particular purpose, a response surface design could be used for the proposed methodology. Another extension could be to focus on more than one response variable for some process optimization problems. In addition, the MSE model could be used in the optimization step in order to eliminate a limitation of the proposed process optimization model in this paper. 


\section{REFERENCES}

[1] Montgomery, D. C. (2012). Introduction to Statistical Quality Control. New York: John Wiley \& Sons Inc., New York, USA.

[2] Vining, G. G., \& Myers, R. H. (1990). Combining Taguchi and response surface philosophies: a dual response approach. Journal of Quality Technology, 22(1), 38-45.

[3] Del Castillo, E., \& Montgomery, D. C. (1993). A nonlinear programming solution to the dual response problem. Journal of Quality Technology, 25(3), 199-204.

[4] Lin, D. K., \& Tu, W. (1995). Dual response surface optimization. Journal of Quality Technology, 27(1), 3439.

[5] Copeland, K. A., \& Nelson, P. R. (1996). Dual response optimization via direct function minimization. Journal of Quality Technology, 28(3), 331-336.

[6] Ames, A. E., Mattucci, N., Macdonald, S., Szonyi, G., \& Hawkins, D. M. (1997). Quality loss functions for optimization across multiple response surfaces. Journal of Quality Technology, 29(3), 339-346.

[7] Borror, C. M. (1998). Mean and variance modeling with qualitative responses: A case study. Quality Engineering, 11(1), 141-148.

[8] Kim, K. J., \& Lin, D. K. (1998). Dual response surface optimization: a fuzzy modeling approach. Journal of Quality Technology, 30(1), 1-10.

[9] Kim, Y. J., \& Cho, B. R. (2000). Economic integration of design optimization. Quality Engineering, 12(4), 561-567.

[10] Kim, Y. J., \& Cho, B. R. (2002). Development of priority-based robust design. Quality Engineering, 14(3), 355-363.

[11] Tang, L. C., \& Xu, K. (2002). A unified approach for dual response surface optimization. Journal of Quality Technology, 34(4), 437-447.

[12] Ding, R., Lin, D. K., \& Wei, D. (2004). Dual-response surface optimization: a weighted MSE approach. Quality Engineering, 16(3), 377-385.

[13] Shin, S., Samanlioglu, F., Cho, B. R., \& Wiecek, M. M. (2011). Computing trade-offs in robust design: perspectives of the mean squared error. Computers \& Industrial Engineering, 60(2), 248-255.

[14] Köksoy, O. (2006). Multiresponse robust design: Mean square error (MSE) criterion. Applied Mathematics and Computation, 175(2), 1716-1729.

[15] Park, H., Park, S. H., Kong, H. B., \& Lee, I. (2012). Weighted sum MSE minimization under per-BS power constraint for network MIMO systems. IEEE Communications Letters, 16(3), 360-363.

[16] Shaibu, A. B., \& Cho, B. R. (2009). Another view of dual response surface modeling and optimization in robust parameter design. The International Journal of Advanced Manufacturing Technology, 41(7-8), 631641.

[17] Costa, N. R. P. (2010). Simultaneous optimization of mean and standard deviation. Quality Engineering, 22(3), 140-149.

[18] Park, C. (2013). Determination of the joint confidence region of the optimal operating conditions in robust design by the bootstrap technique. International Journal of Production Research, 51(15), 4695-4703. 
[19] Shin, S., Truong, N. K. V., Goethals, P. L., Cho, B. R., \& Jeong, S. H. (2014). Robust design modeling and optimization of a multi-response time series for a pharmaceutical process. The International Journal of Advanced Manufacturing Technology, 74(5-8), 1017-1031.

[20] Chan, H. L., \& Ozdemir, A. (2017). The development of a customer-centred, response surface methodologybased robust parameter design optimisation model under a moderately skewed production process. International Journal of Experimental Design and Process Optimisation, 5(4), 255-284.

[21] Ozdemir, A., \& Cho, B. R. (2016). A nonlinear integer programming approach to solving the robust parameter design optimization problem. Quality and Reliability Engineering International, 32(8), 28592870 .

[22] Ozdemir, A., \& Cho, B. R. (2017). Response surface-based robust parameter design optimization with both qualitative and quantitative variables. Engineering Optimization, 49(10), 1796-1812.

[23] Lu, Y., Wang, S., Yan, C., \& Huang, Z. (2017). Robust optimal design of renewable energy system in nearly/net zero energy buildings under uncertainties. Applied Energy, 187, 62-71.

[24] Chatterjee, K., Drosou, K., Georgiou, S. D., \& Koukouvinos, C. (2018). Response modelling approach to robust parameter design methodology using supersaturated designs. Journal of Quality Technology, 50(1), 66-75.

[25] Ouyang, L., Ma, Y., Wang, J., Tu, Y., \& Byun, J. H. (2018). An interval programming model for continuous improvement in micro-manufacturing. Engineering Optimization, 50(3), 400-414.

[26] Özdemir, A. (2019). A mixed integer linear programming model for finding optimum operating conditions of experimental design variables using computer-aided optimal experimental designs. Uluslararast Mühendislik Araştırma ve Geliştirme Dergisi, 11(2), 551-559.

[27] Ozdemir, A., \& Cho, B. R. (2019). Response surface optimization for a nonlinearly constrained irregular experimental design space. Engineering Optimization, 51(12), 2030-2048.

[28] Myers, R. H., Montgomery, D. C., \& Anderson-Cook, C. M. (2016). Response surface methodology: process and product optimization using designed experiments. Hoboken: John Wiley \& Sons Inc., New Jersey, USA.

[29] Maple, V., 2013. Waterloo maple software. University of Waterloo Version, 17. 